\title{
Care complexity in hospitalized elderly according to cognitive performance
}

\author{
Complexidade assistencial em idosos hospitalizados conforme desempenho cognitivo \\ Complejidad asistencial en ancianos hospitalizados según desempeño cognitivo
}

Henrique Salmazo da Silva'
ORCID:0000-0002-3888-4214

Beatriz Aparecida Ozello Gutierrez" ORCID: 0000-0001-6901-6439

'Universidade Católica de Brasília. Brasília, Distrito Federal, Brazil. "Universidade de São Paulo. São Paulo, São Paulo, Brazil.

How to cite this article:

Salmazo-Silva H, Gutierrez BAO. Care complexity in hospitalized elderly according to cognitive performance. Rev Bras Enferm. 2019;72(Suppl 2):134-9. doi: http://dx.doi.org/10.1590/0034-7167-2018-0357

Corresponding Author:

Henrique Salmazo da Silva

E-mail: henriquesalmazo@yahoo.com.br

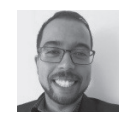

Submission: $05-29-2018$

Approval: 08-21-2018

\begin{abstract}
Objective: to investigate possible differences in care complexity, functional performance and biopsychosocial and health system aspects among hospitalized elderly with or without cognitive decline. Method: quantitative, cross-sectional and analytical study in which was used the INTERMED method and cognitive and functional screening scales. We investigated 384 elderly patients admitted to a medical and surgical clinic of a University Hospital located in São Paulo/SP. Results: cognitive decline was present in $40.1 \%$ of the sample, most of them were longer-lived elderly individuals with less schooling and income, more dependent in activities of daily living and had greater vulnerability in different domains of INTERMED. After adjustments, the elderly with cognitive decline presented greater vulnerability in the psychological domain. Conclusion: the relationship between cognitive decline and psychological vulnerability highlights the need to adopt long-term care based on involvement of the family, health team and different services, thereby maximizing the quality of care.
\end{abstract}

Descriptors: Elderly; Cognitive Decline; Behavioral Symptoms; Comprehensive Health Care; Hospital.

\section{RESUMO}

Objetivo: investigar possíveis diferenças na complexidade assistencial, desempenho funcional e aspectos biopsicossociais e de sistema de saúde entre idosos hospitalizados com ou sem declínio cognitivo. Método: estudo quantitativo, transversal e analítico que utilizou o método INTERMED e escalas de rastreio cognitivo e funcional. Foram investigados 384 idosos internados em clínica médica e cirúrgica de um Hospital Universitário em São Paulo/SP. Resultados: Houve declínio cognitivo em 40,1\% da amostra, cuja maior parte era de idosos mais longevos e do sexo feminino, com menor escolaridade e renda, mais dependentes para as atividades de vida diária e com maior vulnerabilidade em diferentes domínios do INTERMED. Após ajustes, os idosos com declínio cognitivo apresentaram maior vulnerabilidade no domínio psicológico. Conclusão: A relação entre declínio cognitivo e vulnerabilidade psicológica destaca a necessidade de adotar cuidados de longa duração pautados no envolvimento da família, da equipe de saúde e dos diferentes serviços para qualidade da assistência.

Descritores: Idoso; Cognição; Sintomas Comportamentais; Assistência Integral à Saúde; Hospital.

\section{RESUMEN}

Objetivo: investigar posibles diferencias en la complejidad asistencial, desempeño funcional, y en los aspectos biopsicosociales y del sistema de salud entre ancianos hospitalizados con o sin declinación cognitiva. Método: estudio cuantitativo, transversal y analítico que utilizó el método INTERMED y escalas de rastreo cognitivo y funcional. Se investigaron 384 ancianos internados en clínica médica y quirúrgica de un Hospital Universitario ubicado en São Paulo/SP. Resultados: se obtuvo que el 40,1\% de la muestra presentó declinación cognitiva, la mayoría compuesta por ancianos más longevos, del sexo femenino, con menor escolaridad e ingresos, más dependientes para las actividades de vida diaria y con mayor vulnerabilidad en diferentes dominios del INTERMED. Después de ajustes, los ancianos con declinación cognitiva presentaron mayor vulnerabilidad en el dominio psicológico. Conclusión: la relación entre declinación cognitiva y vulnerabilidad psicológica destaca la necesidad de adoptar cuidados de larga duración basados en la participación de la familia, del equipo de salud y de los diferentes servicios, maximizando la calidad de la atención.

Descriptores: Anciano; Cognición; Síntomas Conductuales; Atención Integral de Salud; Hospital. 


\section{INTRODUCTION}

Care to hospitalized elderly individuals challenges health care managers and professionals, and demands adopting practices aimed at care management and implementation of technologies for the evaluation, planning and monitoring of care ${ }^{(1)}$. Unlike other population segments, chronic diseases and functional disabilities that may aggravate the health status prognosis are more prevalent in the elderly and, if not adequately monitored, will result in death ${ }^{(2-5)}$. In a study conducted with elderly people in a university hospital in the northern state of Minas Gerais, $12.7 \%$ of the sample presented unsatisfactory evolution, with unchanged clinical status or evolution to death ${ }^{(5)}$.

Faced with this problem, some studies were conducted with the aims of raising aggravating factors in the health/illness status of elderly patients, improving the quality of care provided to them, and reducing care costs ${ }^{(6-11)}$. Some clinical management tools are used to identify biopsychosocial and health system aspects that can improve care for hospitalized elderly, such as the INTERMED method $^{(11-17)}$. In Brazil, the application of these tools still lacks research, especially to identify elderly subjects with functional and cognitive limitations, who are generally more susceptible to adverse health outcomes in the context of long-term care ${ }^{(18)}$.

In a longitudinal study, elderly beneficiaries of health insurance were evaluated for ten years and patients with dementia syndrome had an increased risk of hospitalization, greater length of stay in the hospital and higher health care-related expenses ${ }^{(19)}$. Functional and cognitive states moderated these results ${ }^{(19)}$.

In previous studies evaluating adult and elderly patients with liver and psychiatric disorders, the INTERMED method was sensitive to identify complex medical conditions and severe physiological reactions. However, the acuity was not the same for detecting psychiatric symptoms in the sample ${ }^{(11)}$. Therefore, the following question of this study: is the cognitive decline of hospitalized elderly people associated with greater care complexity and differences in biopsychosocial and health aspects?

\section{OBJECTIVE}

To investigate possible differences between groups of hospitalized elderly with or without cognitive decline in relation to care complexity, biopsychosocial and health aspects, and functional performance.

\section{METHOD}

\section{Ethical aspects}

Ethical principles involving research with human beings determined by the National Health Council were respected after approval by the Research Ethics Committee of the University Hospital of the University of São Paulo (HU-USP). All participants signed the Informed Consent form to guarantee participants' autonomy and the anonymity and secrecy of information.

\section{Design, place of study and period}

Quantitative, cross-sectional and analytical study conducted in the medical clinic and surgical clinic of the University Hospital, located in the western area of the city of São Paulo between years 2010 and 2012 .

\section{Sample and inclusion and exclusion criteria}

This was a convenience sample of 382 elderly people who met the following inclusion criteria: aged 60 years and over, hospitalized for more than 48 hours, acceptance to participate in the study and signature of the Informed Consent form. Patients with aphasia and a diagnosis of advanced dementia were excluded.

\section{Collection and organization of data}

For characterization of participants, sociodemographic data (name, sex, age, occupation, self-reported race, income, marital status and family life) were collected from medical records. The INTERMED method was used for data collection. This tool is based on data from medical records and semi-structured interviews with patients. The interview included an anamnesis of data on biopsychosocial and health system aspects.

The INTERMED method is composed of 17 open questions that guide the completion of a table with 20 variables that cover the history, current state, and vulnerability related to the biological, psychological, social and health system domains. The completion is according to interviewees' responses. The purpose of INTERMED is to improve information and communication among professionals regarding patients' health risks and needs in order to counteract those risks and promote preventive and cost-effective care ${ }^{(15)}$.

In previous studies, the use of the INTERMED method demonstrated reliability of results by integrating the biopsychosocial aspects of the disease and its relationship between the patient and the health system, and offering support for case management with the interprofessional team ${ }^{(15)}$. This method has applications in clinical management (evaluation of case complexity and health needs), in the production of new knowledge (description of different comorbidities, population stratification in randomized clinical trials), education and evaluation of health care outcomes (quality management) ${ }^{(15-17)}$.

The scores for each domain of the INTERMED method obey a Likert scale with values estimated from 0 to 3 . Scores are classified in ascending order of complexity; the score 0 (zero) corresponds to the absence of complexity, and 3 (three) corresponds to the highest level of complexity of a given variable. The sum of the 20 variables ranges from 0 to 60 points and indicates the degree of patient care complexity ${ }^{(20)}$. In this study, the cutoff point equal to or greater than 20 was used to define "complex" elderly individuals with indication of integrated treatment ${ }^{(21,22)}$. Elderly subjects with scores of less than 20 were classified as "non-complex".

Cases of cognitive decline were identified through the Mini Mental State Examination (MMSE) (Bertolucci et al., 1994). The score equivalent to the standard deviation below the medians proposed by Brucki et al. (2003) was considered as follows: illiterates: 17 points; 1-4 years of schooling: 21 points; $5-8$ years: 24 points; $9-11$ years: 26 points; 12 years or more: 27 points ${ }^{(23,24)}$. In order to evaluate the elderly's level of functional capacity in daily life activities related to self-care, was applied the Katz Scale, and the sample was classified as independent, semi-dependent or dependent ${ }^{(25)}$. 


\section{Analysis of results and statistics}

Data were analyzed using the Statistical Package for the Social Sciences (SPSS), version 17. For bivariate analyzes, were used non-parametric tests. Associations with $p$-value below 0.20 were hierarchized to form a multiple logistic regression model. The models were constructed based on the Forward Stepwise method of Wald and adjustments for sociodemographic variables (Model 1) and functional dependence (Model 2). In the final model, were inserted the variables of domains of the INTERMED method, total INTERMED, care complexity, sociodemographic and functional performance variables that remained with $p$-value equal to or below 0.05 (Model 3). The dependent variable was categorized as " 0 " and " 1 "; in which 0 corresponded to the group of elderly without cognitive decline and 1 was the group of elderly individuals with cognitive decline. For all analyzes, was used a significance level of $5 \%(p<0.05)$.

\section{RESULTS}

A higher prevalence of cognitive decline was observed in elderly women of advanced age, widows, with lower education and lower income (Table 1), and among elderly people more dependent in basic activities of daily living with higher scores in domains of the INTERMED method and greater care complexity, according to Table 2 . No associations were observed between cognitive decline, days of hospitalization and area of origin: medical and surgical clinic.

Table 1 - Sociodemographic characteristics associated with the cognitive decline of study participants, São Paulo, São Paulo, Brazil, 2010-2012

\begin{tabular}{|c|c|c|c|}
\hline $\begin{array}{l}\text { Sample characteristics } \\
(\mathrm{N}=382)\end{array}$ & $\begin{array}{c}\text { No decline } \\
(n=229) \\
n(\%)\end{array}$ & $\begin{array}{l}\text { With decline } \\
\text { (n=153) } \\
n(\%)\end{array}$ & $\begin{array}{c}p \\
\text { value }\end{array}$ \\
\hline \multicolumn{4}{|l|}{ Sex } \\
\hline Male & $116(65.91)$ & $60(34.09)$ & \multirow[t]{2}{*}{0.028} \\
\hline Female & $113(54.85)$ & $93(45.15)$ & \\
\hline \multicolumn{4}{|l|}{ Age } \\
\hline $60 \mid-69$ & $105(66.46)$ & $53(33.54)$ & \multirow[t]{3}{*}{0.000} \\
\hline $70 \mid-80$ & $91(64.54)$ & $50(35.46)$ & \\
\hline $80 \mid-+$ & $33(39.76)$ & $50(60.24)$ & \\
\hline \multicolumn{4}{|l|}{ Schooling (years) } \\
\hline No schooling & $24(32.88)$ & $49(67.12)$ & \multirow[t]{3}{*}{0.000} \\
\hline$<8$ years & $180(65.93)$ & $93(34.07)$ & \\
\hline$>8$ years & $25(69.44)$ & $11(30.56)$ & \\
\hline \multicolumn{4}{|l|}{ Self-reported race } \\
\hline White & $159(62.6)$ & $95(37.4)$ & \multirow[t]{4}{*}{0.245} \\
\hline Mixed race & $29(49.15)$ & $30(50.85)$ & \\
\hline Black & $36(57.14)$ & $27(42.84)$ & \\
\hline Asian & $5(83.33)$ & $1(16.67)$ & \\
\hline \multicolumn{4}{|l|}{ Marital status } \\
\hline Married & $121(67.98)$ & $57(32.02)$ & \multirow[t]{3}{*}{0.007} \\
\hline Widowed & $68(52.31)$ & $62(47.69)$ & \\
\hline Single or separated & $40(54.05)$ & $34(45.95)$ & \\
\hline \multicolumn{4}{|c|}{ Income (number of minimum wages) } \\
\hline No income & $59(47.97)$ & $64(52.03)$ & \multirow[t]{5}{*}{0.004} \\
\hline 1 & $115(64.97)$ & $62(35.03)$ & \\
\hline 2 & $34(70.83)$ & $14(29.17)$ & \\
\hline 3 & $6(50)$ & $6(50)$ & \\
\hline 4 & $14(66.67)$ & 7 (33.33) & \\
\hline
\end{tabular}

Table 2 - Functional capacity, INTERMED domains and care complexity associated with the cognitive decline of study participants, São Paulo, São Paulo, Brazil, 2010-2012

\begin{tabular}{lccc}
\hline $\begin{array}{l}\text { Sample characteristics } \\
\text { (N=382) }\end{array}$ & $\begin{array}{c}\text { No decline } \\
(\mathbf{n = 2 2 9 )} \mathbf{n}(\%)\end{array}$ & $\begin{array}{c}\text { With decline } \\
(\mathbf{n}=\mathbf{1 5 3}) \mathbf{n}(\%)\end{array}$ & $\boldsymbol{p}$ value \\
\hline $\begin{array}{l}\text { Functional capacity } \\
\text { Independent }\end{array}$ & $164(68)$ & $77(32)$ & 0.000 \\
$\quad$ Semi-dependent & $40(65)$ & $21(34.4)$ & \\
$\quad$ Dependent & $25(31.2)$ & $55(68)$ & \\
& M (+DP) & M (+DP) & \\
Days of hospitalization & $15.40(11.56)$ & $17.25(17.89)$ & 0.682 \\
INTERMED & & & \\
$\quad$ Biological domain & $7.80(2.42)$ & $8.47(2.44)$ & 0.005 \\
$\quad$ Psychological domain & $1.57(2.35)$ & $3.50(3.19)$ & 0.000 \\
$\quad$ Social domain & $2.20(2.30)$ & $3.95(3.65)$ & 0.000 \\
$\quad$ Health system domain & $4.27(1.90)$ & $4.38(1.92)$ & 0.385 \\
$\quad$ INTERMED Total & $15.88(5.80)$ & $20.39(7.79)$ & 0.000 \\
Care complexity & & & \\
$\quad$ | |- 20 & $183(69.8)$ & $79(30.2)$ & 0.000 \\
21 |- + & $46(38.3)$ & $74(61.7)$ & \\
\hline
\end{tabular}

Regarding the multiple logistic regression models, sex, income, biological and social domain and care complexity lost statistical significance (not shown in the text). The variables that remained associated with cognitive decline were: age, schooling, marital status and the psychological domain of the INTERMED method. Together, these data indicated that elderly people with cognitive decline had more vulnerability in the psychological domain, even after adjusting the sociodemographic characteristics related to the degree of dependence in activities of daily living, according to Model 3 presented in Table 3.

Table 3 - Multiple Logistic Regression block models - Forward Stepwise method, São Paulo, São Paulo, Brazil, 2010-2012

\begin{tabular}{lcccc}
\hline $\begin{array}{l}\text { Model } 1 \\
\text { Sociodemographic } \\
\text { characteristics }\end{array}$ & B (SE) & OR & Cl (95\%) & $\boldsymbol{p}$ value \\
\hline Age & $0.33(0.13)$ & 1.03 & $1.01-1.06$ & 0.010 \\
Schooling & $-0.881(0.22)$ & 0.41 & $0.26-0.64$ & 0.000 \\
Marital status (no partner) & $0.51(0.22)$ & 1.67 & $1.08-2.58$ & 0.020 \\
Constant (B0) & $-2.26(0.951)$ & & & 0.017 \\
\hline
\end{tabular}

Model 2

Sociodemographic and health $\quad B(\mathrm{SE}) \quad$ OR $\quad \mathrm{Cl}(95 \%) \quad p$ value characteristics

Age

Schooling

Marital status (no partner)

Katz (1 or more difficulty)

Constant (B0)

$\begin{array}{cccc}0.27(0.13) & 1.03 & 1.002-1.05 & 0.033 \\ -0.87(0.23) & 0.41 & 0.26-0.64 & 0.000 \\ 0.41(0.22) & 1.51 & 0.97-2.37 & 0.067 \\ 0.75(0.23) & 2.11 & 1.37-3.33 & 0.001 \\ -2.09(0.94) & & & 0.028\end{array}$

Model 3

Sociodemographic and health characteristics, and measures of the INTERMED method*

\begin{tabular}{lcccc}
\hline Age & $0.33(0.01)$ & 1.03 & $1.01-1.06$ & 0.018 \\
Schooling & $-0.98(0.24)$ & 0.37 & $0.23-0.59$ & 0.000 \\
Marital status (no partner) & $0.34(0.23)$ & 1.41 & $0.89-2.25$ & 0.141 \\
Katz (1 or more difficulty) & $0.440(0.24)$ & 1.55 & $0.95-2.52$ & 0.075 \\
Psychological domain & $0.24(0.04)$ & 1.27 & $1.16-1.38$ & 0.000 \\
Constant (B0) & $-2.79(1.02)$ & & & 0.006 \\
\hline
\end{tabular}

Note: * Final model: chi-square of the model of 80.52, degrees of freedom: $5, p .0,000 . R 2=0.257$ $B$ - Beta; Cl - Confidence Interval; OR - Odds Ratio; SE - Standard Error; The variables age and schooling were continuous and the reference condition for marital status was the married group, and for Katz - functional dependence, the group of independent elderly. 


\section{DISCUSSION}

The results of this study indicated that hospitalized elderly people with cognitive decline are a longer-lived sample with lower educational level, more dependent in activities of daily living and more psychologically vulnerable according to the INTERMED method. Together, these data suggest that behavioral aspects should be considered by the nursing team, health professionals, family members, and caregivers who accompany these patients.

From the hospital staff's point of view, it is essential to evaluate in detail if psychological vulnerability conditions are recent, the possible causal factors (physiological, psychic, environmental and social) and the available resources of patients and families for dealing with issues imposed by functional disability, cognitive decline and morbidities of the elderly. It is key to assess caregivers' mental health, their knowledge about illnesses and the patient's condition, and the emotional, instrumental, and financial support network that could be mobilized to cope with possible difficulties associated with care ${ }^{(26,27)}$. This is especially important for: a) care management and resource allocation; b) underlying diagnoses to psychological vulnerability, such as neuropsychiatric symptoms, mental illnesses and delirium itself, which is an acute confusional state of high prevalence in hospitalized elderly; c) avoidance of iatrogenic conducts that may worsen the general health of the elderly; and finally, d) family involvement in the planning of care and hospital discharge by aiming at the quality of continuity of care after hospital discharge.

Regarding patients' psychic state, agitation is one of the most prevalent behaviors in dementias, and observed in $55 \%$ of patients in long-term care institutions ${ }^{(28)}$. Communication between professionals and family members is essential for adjusting the feelings of lack of hope, loneliness and loss of control. The transition of patients with cognitive disorders to the hospital should include family members and patients in care planning ${ }^{(29)}$.

Hence the need to implement public policies focused on home care and long-term care that strengthen family care ${ }^{(30)}$. Within the context of dementias, the costs associated with institutionalization and tertiary care of these elderly people justify prevention policies, the importance of Day Centers for the Elderly (Portuguese acronym: CDI) and home care ${ }^{(1)}$. In Brazil, these home care and CDI initiatives are still incipient, which hinders the effectiveness of long-term care for the elderly with physical dependence and cognitive decline.

The association between cognitive decline and age is well established in the literature and prevalence of dementia is higher in longer-lived elderly ${ }^{(31)}$. The estimate of this prevalence is around $50 \%$ among elderly subjects aged 85 years or older ${ }^{(32)}$. In the present study, the prevalence of cognitive decline was $40.1 \%$, which may be associated with the age profile, since most of the sample was 70 years old or older and hospitalized. These factors may predispose to greater cognitive decline by decompensated clinical conditions.

The relationship between cognitive decline, schooling and sex has also been described and is more commonly found in elderly individuals with less schooling and in elderly women, probably because they are more long-lived and less educated. This fact was confirmed in regression models, where sex lost statistical significance after adjustment of the other sociodemographic variables. It seems the same occurred with marital status, which lost statistical significance after adjustments of the model. In addition to these variables, the elderly with cognitive decline also have a higher prevalence of functional decline in activities of daily living ${ }^{(31)}$.

The greater care complexity detected in patients with cognitive decline included in this study is in line with findings in the literature regarding the INTERMED method, since it extends the clinical scope beyond the biomedical aspect ${ }^{(18)}$. Faced with this need of biopsychosocial vision, the coordination of care is important to favor its integrality ${ }^{(33-36)}$.

\section{Limitations of the study}

The prevalence of cognitive decline in the sample was relatively higher than in community-dwelling older adults. Although adjusted for health and sociodemographic conditions, data from the psychological domain of INTERMED may have been influenced by the health frailty associated with hospitalization and factors such as fear, uncertainty, disorientation in time and space, and difficulties with communication and expression of feelings. Another limitation refers to the absence of previous data of patients; for how long they have had cognitive decline, and how many had properly diagnosed and treated dementia syndromes.

\section{Contributions to the area of nursing, health or public policy}

Despite the limitations of the study, its results contribute to alert and sensitize health professionals to the importance of screening and evaluation of the elderly's cognition during the hospitalization process. In addition, given the conceptual and operational structure of the INTERMED method, the care manager can use this method as a tool for the evaluation of biopsychosocial and health system aspects of hospitalized elderly, which improves the quality of care. This is a valuable tool for health professionals, policy makers and hospital managers when dealing with complex patients with psychosocial comorbidities and poor responses to traditional medical treatments.

\section{CONCLUSION}

Data from the present study indicated, after using the INTERMED method, that hospitalized elderly subjects with cognitive decline were less educated, longer-lived, more dependent and had more vulnerability in the psychological domain. Therefore, the tool was useful to evaluate the biopsychosocial aspects of hospitalized elderly with cognitive decline. The relationship between cognitive decline and psychological vulnerability highlights the need for long-term care based on involvement of the family, health team and the different services to maximize the quality of care. This way, it will be possible to use case management technologies to avoid successive hospitalizations and provide more effective and efficient interventions. To this end, it is essential to rethink hospital care for these elderly people, qualify professionals, provide human resources for case management, and implement information systems through which managers can quantify the impact of interventions for the reduction of iatrogenesis and costs.

\section{ACKNOWLEDGMENTS}

To Universitary Hospital, pacients, and undergratuate students of Gerontology at EACH/USP. 


\section{REFERENCES}

1. Marcoux V, Chouinard M-C, Diadiou F, Dufour I, Hudon C. Screening tools to identify patients with complex health needs at risk of high use of health care services: a scoping review. PLoS ONE. 2017. [cited 2018 Mar 20];12(11):e0188663. Available from: http://journals.plos.org/ plosone/article?id=10.1371/journal.pone.0188663

2. Castro VC, Borghu AC, Mariano PP, Fernandes CAM, Mathias TAF, Carreira L. Perfil de internações hospitalares de idosos no âmbito do Sistema Único de Saúde. Rev Rene[Internet]. 2013 [cited 20182018 Mar 20];14(4):791-800. Available from: http://www.periodicos.ufc.br/ rene/article/view/3547/2787

3. Santos MIPO, Griep RH. Capacidade funcional de idosos atendidos em um programa do SUS em Belém (PA) Ciênc Saúde Colet[Internet]. 2013 [cited 2018 Mar 20];18(3):753-61. Available from: http://www.scielo.br/pdf/csc/v18n3/21.pdf

4. Pinheiro FM, Santo FHE, Chibante CLP, Pestana LC. Perfil de idosos hospitalizados segundo Virginia Henderson: contribuições para o cuidado em enfermagem. Rev Pesqui: Cuid Fundam [Internet]. 2016 [cited 2018 Mar 20];8(3):4789-95. Available from: http://www.seer.unirio.br/ index.php/cuidadofundamental/article/view/4292/pdf

5. Rabelo LPO, Vieira MA, Caldeira AP, Costa SM. Perfil de idosos internados em um hospital universitário. Rev Mineira Enferm[Internet]. 2010 [cited 2018 Mar 20];14(3): 293-300. Available from: http://www.revenf.bvs.br/pdf/reme/v14n3/v14n3a02.pdf

6. Huyse et al. "INTERMED”: a method to assess health service needs. Results on its validity and clinical use. Gen Hosp Psychiatr[Internet]. 1999 [cited 2018 Mar 20];21:39-48. Available from: https://www.sciencedirect.com/science/article/pii/S0163834398000619?via\%3Dihub

7. Donze J', Aujesky D, Williams D, Schnipper JL. Potentially Avoidable 30-Day Hospital Readmissions in Medical Patients. JAMA Intern Med[Internet]. 2013 [cited 2018 Mar 20];173(8): 632-38. Available from: http://www.aahs.org/medstaff/wp-content/uploads/JAMAhospitalreadmissions2013.pdf

8. Hekkert K, Brug F, Borghans I, Cihangir S, Zimmerman C, Gert Westert G, Kool RB. How to identify potentially preventable readmissions by classifying them using a national administrative database. Int J Qual Health Care[Internet]. 2017[cited 2018 Mar 20];29(6):826-32 Available from: https://academic.oup.com/intqhc/article-abstract/29/6/826/4107188?redirectedFrom=fulltext

9. Perkes d, Chen A, Schore J, Brown R. Effects of care coordination on hospitalization, quality of care, and health care expenditures among Medicare beneficiaries. JAMA[Internet]. 2009 [cited 2018 Mar 20];301(6):603-18. Available from: https://jamanetwork.com/journals/jama/ fullarticle/183370

10. Sochalski J, Jaarsma T, Krumholz HM, Laramee A, McMur JJV. What Works In Chronic Care Management: The Case Of Heart Failure. Health Affairs[Internet]. 2009 [cited 2018 Mar 20];28 (1):179. Available from: https://www.healthaffairs.org/doi/full/10.1377/hlthaff.28.1.179

11. Thurber S, Wilson A, Realmuto G, Specker S. The relationship between the INTERMED patient complexity instrument and Level of Care Utilization System (LOCUS). Int J Psychiatr Clin Pract[Internet]. 2017 [cited 2018 Mar 20];80-2. Available from: https://www.tandfonline.com/ doi/full/10.1080/13651501.2017.1353635?scroll=top\&needAccess=true2017. doi:10.1080/13651501.2017.1353635

12. INTERMED Foudation. [Homepage] [Internet]. 2009[cited 2016 May 16]. Available from: www.intermedfoundation.org

13. Matsuki M, Mizushima H, Matsuki H, Ohmura Y, Horikawa N The INTERMED Japanese version: inter-rater reliability and internal consistency. J Psychosom Res[Internet]. 2010 [cited 2018 Mar 20];69(6):583-6. Available from: http://www.jpsychores.com/article/S0022-3999(10)00106-6/pdf

14. Peters LL, Boter H, Slaets JP, Buskens E. Development and measurement properties of the self assessment version of the INTERMED for the elderly to assess case complexity. J Psychos Res. 2013. [cited 2018 Mar 20];74(6):518-22. Available from https://linkinghub.elsevier.com/ retrieve/pii/S0022-3999(13)00045-7

15. Huyse FJ, Lyons JS, Stiefel FC, Slaets JPJ, de Jonge P, Fink P, et al. INTERMED: a method to assess health service needs: I. Development and reliability. Gen Hosp Psychiatry[Internet]. 1999 [cited 2018 Mar 20];21(1):39-48. Available from: https://www.sciencedirect.com/science/ article/pii/S0163834398000577?via\%3Dihub

16. Frederich CSCF, Frits P, Huyse J, Guex P, Joris PJ, Slaets JPJ, et al. "INTERMED": a method to assess health service needs: II. Results on its validity and clinical use. Gen Hosp Psychiatry[Internet]. 1999 [cited 2018 Mar 20];21(1):49-56. Available from: https://www.sciencedirect. com/science/article/pii/S0163834398000619?via\%3Dihub

17. Lobo E, Ventura T, Navio M, Santabárbara J , Kathol R, Samaniego E, et al. Identification of componentes of health complexity on internal medicine units by means of the INTERMED method. Int J Clin Pract. [Internet]. 2015 [cited 2018 Mar 20];69(11):1377-86.Available from: https://onlinelibrary.wiley.com/doi/pdf/10.1111/ijcp.12721

18. Gutierrez BAO, Salmazo-Silva H, Shimizu HE. Aspectos biopsicossociais e a complexidade assistencial de idosos hospitalizados. Acta Paul Enferm[Internet]. 2014 [cited 2018 Mar 20];27(5):427-33. Available from: http://www.scielo.br/pdf/ape/v27n5/pt_1982-0194ape-027-005-0427.pdf

19. Zhu CW, Cosentino S, Ornstein K, Gu Y, Andrews H, Stern Y. Use and cost of hospitalization in dementia: longitudinal results from a community-based study. Int J Geriatr Psychiatry[Internet]. 2015 [cited 2018 Mar 20];30(8):833-841. Available from: https://www.ncbi.nlm. nih.gov/pmc/articles/PMC4414886/

20. Hoogervorst EL, De Jonge P, Jelles B, Huyse FJ, Heeres I, van der Ploeg HM, et al. The INTERMED:a screening instrument to identify multiple sclerosis patients in need of multidisciplinary treatment. J Neurol Neurosurg Psychiatry[Internet]. 2003 [cited 2018 Mar 20];74(1):20-4. Available from: https://www.ncbi.nlm.nih.gov/pmc/articles/PMC1738178/pdf/v074p00020.pdf 
21. Koch N, Stiefel F, De Jonge P, Fransen J, Chamot AM, Gerster JC, Huyse F, So AK: Identification of case complexity and increased health care utilization in patients with rheumatoid arthritis. Arthritis Rheum[Internet]. 2001 [cited 2018 Mar 20];45(3):216-21. Available from: https:// onlinelibrary.wiley.com/doi/epdf/10.1002/1529-0131\%28200106\%2945\%3A3\%3C216\%3A\%3AAID-ART251\%3E3.0.CO\%3B2-F

22. De Jonge $\mathrm{P}$, Bauer I, Huyse FJ, Latour CH. Medical inpatients at risk of extended hospital stay and poor discharge health status: detection with COMPRI and INTERMED. Psychosom Med[Internet]. 2003 [cited 2018 Mar 20];65(4):534-41. Available from: https://insights.ovid.com/ pubmed?pmid $=12883102$

23. Bertolucci PH, Brucki SM, Campacci SR, Juliano Y. O mini-exame do estado mental em uma população geral: impacto da escolaridade. Arq Neuropsiquiatr[Internet]. 1994 [cited 2018 Mar 20];52:1-7. Available from: www.scielo.br/pdf/anp/v52n1/01.pdf

24. Bruck SMD, Nitrini R, Caramelli P. Sugestões para o uso do mini-exame do estado mental. Arq Neuropsiquiatr[Internet]. 2003 [cited 2018 Mar 20];61(3-B):777-8. Available from: http://www.scielo.br/pdf/anp/v61n3B/17294.pdf

25. Oliveira DLC, Goretti LC, Pereira LSM. O desempenho de idosos institucionalizados com alterações cognitivas em atividades de vida diária e mobilidade: estudo piloto. Rev Bras Fisioter [Internet]. 2006 [cited 2018 Mar 20];10(1): 91-6. Available from: http://www.redalyc.org/articulo. oa?id=235016476012

26. Giudice D, Watson R. Dementia in older people: an update. Interm Med J[Internet]. 2014 [cited 2018 Mar 20]:44(11): 1066-73. Available from: https://onlinelibrary.wiley.com/doi/epdf/10.1111/imj.12572

27. Loureiro LSN, Fernandes MGM, Marques S, Nóbrega MML, Rodrigues RAP. Sobrecarga de cuidadores familiares de idosos: prevalência e associação com características do idoso e do cuidador. Rev Esc Enferm USP[Internet]. 2013 [cited 2018 Mar 20];47(5):1133-40. Available from: http://www.scielo.br/pdf/reeusp/v47n5/pt_0080-6234-reeusp-47-05-1129.pdf

28. Devshi R, Shaw S, Elliott-King J, Hogervorst E, Hiremath A, Velayudhan L, et al. Prevalence of Behavioural and Psychological Symptoms of Dementia in Individuals with Learning Disabilities. Diagnostics (Basel). [Internet]. 2015[cited 2018 Mar 20];2;5(4):564-76. Available from: https://www.ncbi.nlm.nih.gov/pmc/articles/PMC4728475/

29. Blomer M, Digby R, Tan H, Crawford K, Williams A. The experience of family carers of people who are hospitalized. Dementia (London). 2014;19(2):83-90. doi: 10.1177/1471301214558308

30. Souza LM; Wegner W. Gorini MIPC. Educação em saúde: uma estratégia de cuidado ao cuidador leigo. Rev Latino-Am Enfermagem [Internet]. 2007 [cited 2018 Mar 20]:15(2): Available from: http://www.scielo.br/pdf/rlae/v15n2/pt_v15n2a22.pdf

31. Trindade APNT, Barboza MA, Oliveira FB, Borges APO. Repercussão do declínio cognitivo na capacidade funcional em idosos institucionalizados e não institucionalizados. Fisioter Mov [Internet]. 2013 [cited 2018 Mar 20];26(2):281-89. Available from: http://www. scielo.br/pdf/rlae/v15n2/pt_v15n2a22.pdf

32. Small GW, Donohue JA, Brooks RL. An economic evaluation of donepezil in the treatment of Alzheimer's disease. Clin Ther[Internet]. 1998 [cited 2018 Mar 20];20:838-50. Available from: http://www.clinicaltherapeutics.com/article/S0149-2918(98)80145-8/pdf

33. Perkes d, Chen A, Schore J, Brown R. Effects of care coordination on hospitalization, quality of care, and health care expenditures among Medicare beneficiaries. JAMA[Internet]. 2009 [cited 2018 Mar 20];301(6):603-18. Available from: https://jamanetwork.com/journals/jama/ fullarticle/183370

34. Phillips C. Care coordination for Primary Care Practice. J Am Board Fam Med[Internet]. 2016 [cited 2018 Mar 20];29(6): 649- 51. Available from: http://www.jabfm.org/content/29/6/649.full.pdf+html

35. Struckmann V, Leijten FRM, Ginneken EV, Kraus M, Reiss M, Spranger A, et al. Relevant models and elements of integrated care for multimorbidity: results of a scoping review, Health Policy[Internet]. 2018 [cited 2018 Mar 20]:122(1):23-35. Available from: https://www. sciencedirect.com/science/article/pii/S016885101730221X

36. Heide IVD, Snoeijs S, Quattrini S, Struckmann V, Hujala A, Schellevis F, et al. Patient-centeredness of integrated care programs for people with multimorbidity: results from the European ICARE4EU project. Health Policy[Internet]. 2018 [cited 2018 Mar 20]:122(1):36-43. Available from: https://www.sciencedirect.com/science/article/pii/S0168851017302944 